\title{
Bibliographie annuelle de l'Histoire de France du cinquième siècle à 1958. Année 2002
}

\section{Raymonde Monnier}

\section{(2) OpenEdition \\ 1 Journals}

Édition électronique

URL : https://journals.openedition.org/ahrf/1873

DOI : $10.4000 /$ ahrf.1873

ISSN : 1952-403X

\section{Éditeur :}

Armand Colin, Société des études robespierristes

\section{Édition imprimée}

Date de publication : 1 décembre 2004

Pagination : 187

ISSN : 0003-4436

\section{Référence électronique}

Raymonde Monnier, « Bibliographie annuelle de l'Histoire de France du cinquième siècle à 1958.

Année 2002 », Annales historiques de la Révolution française [En ligne], 338 | octobre-décembre 2004, mis en ligne le 22 mars 2006, consulté le 23 avril 2022. URL : http://journals.openedition.org/ahrf/ 1873 ; DOI : https://doi.org/10.4000/ahrf.1873

Ce document a été généré automatiquement le 23 avril 2022.

Tous droits réservés 


\title{
Bibliographie annuelle de l'Histoire de France du cinquième siècle à 1958. Année 2002
}

\author{
Raymonde Monnier
}

\section{RÉFÉRENCE}

Bibliographie annuelle de l'Histoire de France du cinquième siècle à 1958. Année 2002, Paris, CNRS Editions, 2003, 1119 p., ISBN 2-271-06137-7. $110 €$.

1 Est-il nécessaire de redire l'intérêt de cette publication qui est depuis 1953 si utile pour tous les chercheurs; le nombre très élevé de revues dépouillées est éloquent (1 382 revues françaises et 620 revues étrangères). Les tableaux statistiques qui ouvrent le volume de l'année 2002 montrent que les études consacrées à la Révolution française se maintiennent à un bon niveau: un peu plus de $10 \%$ des références de l'ensemble dépouillé. Le Consulat et l'Empire, actuels bénéficiaires de l'effet bicentenaire, dépassent leur part habituelle. La faveur des historiens pour la Troisième république est nettement confirmée $(22,2 \%)$, doublant le score du $18 \mathrm{e}$ siècle $(11,1 \%)$. Il est difficile de faire à partir d'un comptage, même grossier, une estimation comparée des champs d'intérêt pour la période 1789-1815; ni le plan de classement de la publication ni l'index chronologique ne le permettent vraiment. La statistique générale enregistre une certaine stabilité des champs historiographiques, notamment une présence stable du champ politique ; l'histoire religieuse se maintient, de même que celle des sciences et de l'ensemble enseignement, imprimerie, presse. On note une réelle progression sur la longue durée de l'histoire des institutions.

Comme toujours le système de renvois systématiques facilite la recherche, de même que l'index chronologique, celui des matières (incluant les lieux), et la table des noms d'auteurs, dans un ouvrage qui comporte aussi une liste des périodiques et des Mélanges dépouillés. Merci aux auteurs (Martine Sonnet, Brigitte Keriven, Claude 
Ghiati, Isabelle Havelange) et à l'éditeur de nous donner toujours sous sa forme imprimée cet outil de travail indispensable. 